Technical Note

\title{
Systemic Agro-Homeopathy: A New Approach to Agriculture
}

Francesco Di Lorenzo ${ }^{1}$, Giovanni Dinelli ${ }^{2}$, Ilaria Marotti ${ }^{2}$, Grazia Trebbi ${ }^{2,}{ }^{*}$

1. School of Integrated Medicine of Palermo, Palermo, Italy; E-Mail: francescodilorenzo@hotmail.com

2. Department of Agricultural and Food Sciences, Alma Mater Studiorum-University of Bologna, Bologna, Italy; E-Mails: giovanni.dinelli@unibo.it; Ilaria.marotti@unibo.it; grazia.trebbi@unibo.it

* Correspondence: Grazia Trebbi; E-Mail: grazia.trebbi@unibo.it

Academic Editor: Bruno Galeazzi

Special Issue: $\underline{\text { Homeopathy }}$

OBM Integrative and Complementary Medicine 2021, volume 6 , issue 3

doi:10.21926/obm.icm.2103020
Received: May 11, 2021

Accepted: June 28, 2021

Published: July 12, 2021

\begin{abstract}
Modern agriculture must meet the changing needs of society both in terms of food quality and with regards to the environmental issues related to primary production (e.g., biodiversity, habitats, the quality of water and air, and climate change). In this context, win-win solutions at the farm level are required, with more sustainable food production, as well as, a reduction in air, water, and soil pollution, and loss of biodiversity and natural resources. To address these issues, a new emerging discipline called "systemic agro-homeopathy" is currently being developed. This approach considers plants and their interactions with the environment as a unified agroecosystem, called the "holon" and it is based on the use of substances at ultrahigh dilutions that are safe for farmers and have no ecological side effects. This report describes the principles and the application of this approach.
\end{abstract}

\section{Keywords}

Systemic agro-homeopathy; agro-ecosystems; holon; secondary metabolites; metabolic similarity

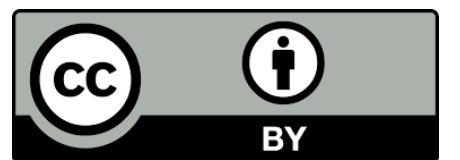

(c) 2021 by the author. This is an open access article distributed under the conditions of the Creative Commons by Attribution License, which permits unrestricted use, distribution, and reproduction in any medium or format, provided the original work is correctly cited. 


\section{Homeopathy in Agriculture}

According to the four principles of organic agriculture, health, ecology, care, and fairness, the substances that are used for the care and nourishment of plants and protection from pests must be safe for people, animals, and the environment. These principles are focused on sustaining and enhancing the health of the soil, plant, humans, and other animals, respect and emulate the ecological systems, and protect the natural resources of the planet for current and future generations. In this context, agro-homeopathy could be an integrative approach to improve organic agriculture since homeopathic treatments, due to their ultrahigh dilutions, have few or no ecological side effects. In recent years there has been a growing interest of the scientific community in such methods, and many scientific studies have been performed to evaluate the effect of homeopathic treatments on plants [1-10]. Different plant model systems have been set up both in basic research (in vitro germination and growth models with healthy, impaired, and phytopathological models) [15] and in application research (field trials) [2]. Experimental research on healthy and stressed plants has shown the potential of homeopathic treatments to influence plants by enhancing growth parameters, increasing germination rate and defensive substances, and strengthening plants against pathogen and pest attacks [6-10].

Homeopathy is a clinical-therapeutic method developed in 1796 by Samuel Hahnemann (17551843) and depends on three principles: the similarity, the individualization of cases, and the infinitesimal. In particular, the principle of similarity (treat likes by likes) is generally considered to be one of the pillars of homeopathy and states that a patient should be treated with a substance which, in a healthy person, cause symptoms similar to those presented by the affected person [11].

The homeopathic method was developed and formulated primarily for humans and not for plants, and its application in agriculture can only be successful after considering the differences between plants and animals. The attempt to apply the homeopathic treatment designed for humans on plant systems without any type of adaptation inevitably fails [12-13]. On the other hand, the Hahnemann principles are universal and can be applied to many biological systems, including those in the plant kingdom, but the selection of the right remedy for healing plants based on the Hahnemann Materia Medica is probably an incorrect approach. We can identify at least two main logical reasons supporting this conclusion. The first is the evidence that plants exhibit very different morphology and biochemistry compared to humans and other animals. In Table 1, the main differences between plant and animal cells are presented.

Table 1 The main morphological and biochemical differences between plant and animal cells.

\begin{tabular}{lll}
\hline Features & Plant cell & Animal cell \\
\hline Cells shape & Has distinct edges, usually square & Is regular and round shape \\
& or rectangular shape & \\
Cell wall & Present & Absent \\
Nucleus & Located on one side of the cell & Located in the center of the cell \\
Lysosomes & Present but very rare & Present \\
Centrosomes & Absent & Present \\
Plastids & Present & Absent \\
\hline
\end{tabular}




\begin{tabular}{lll}
\hline Vacuoles & Few large, centrally positioned & Usually small and numerous \\
Mitochondria & $\begin{array}{l}\text { Present, fewer in number in green } \\
\text { tissues, insensible to cyanide }\end{array}$ & $\begin{array}{l}\text { Present, numerous, susceptible } \\
\text { to cyanide }\end{array}$ \\
Essential nutrients & $\begin{array}{l}\text { Amino acids, vitamins and } \\
\text { coenzymes synthesized }\end{array}$ & $\begin{array}{l}\text { Amino acids, vitamins and } \\
\text { coenzymes not synthesized } \\
\text { Secondary }\end{array}$ \\
Present & Absent \\
metabolism & & \\
\hline
\end{tabular}

The second logical reason is the evidence that the defense mechanisms of plants are different from those of animals. In plants, one of the most common defense mechanisms is based on necrosis (a sort of programmed apoptosis), where the pathogen gets trapped in "death" tissues. The plants sacrifice their tissues to prevent the spread of the pathogen. In plants, another common defense mechanism is the production of secondary metabolites for the intoxication of the pathogen. In animals, the defense mechanisms are based on specialized tissues (lymph nodes, thymus, spleen, etc.), specialized cells (e.g., lymphocyte, macrophage), and specific protein compounds (immunoglobulins). Finally, the plant cell receptors and signaling pathways involved in recognition of pathogenic microorganisms are different from those involved in recognition of pathogens in animal cells (Figure 1).
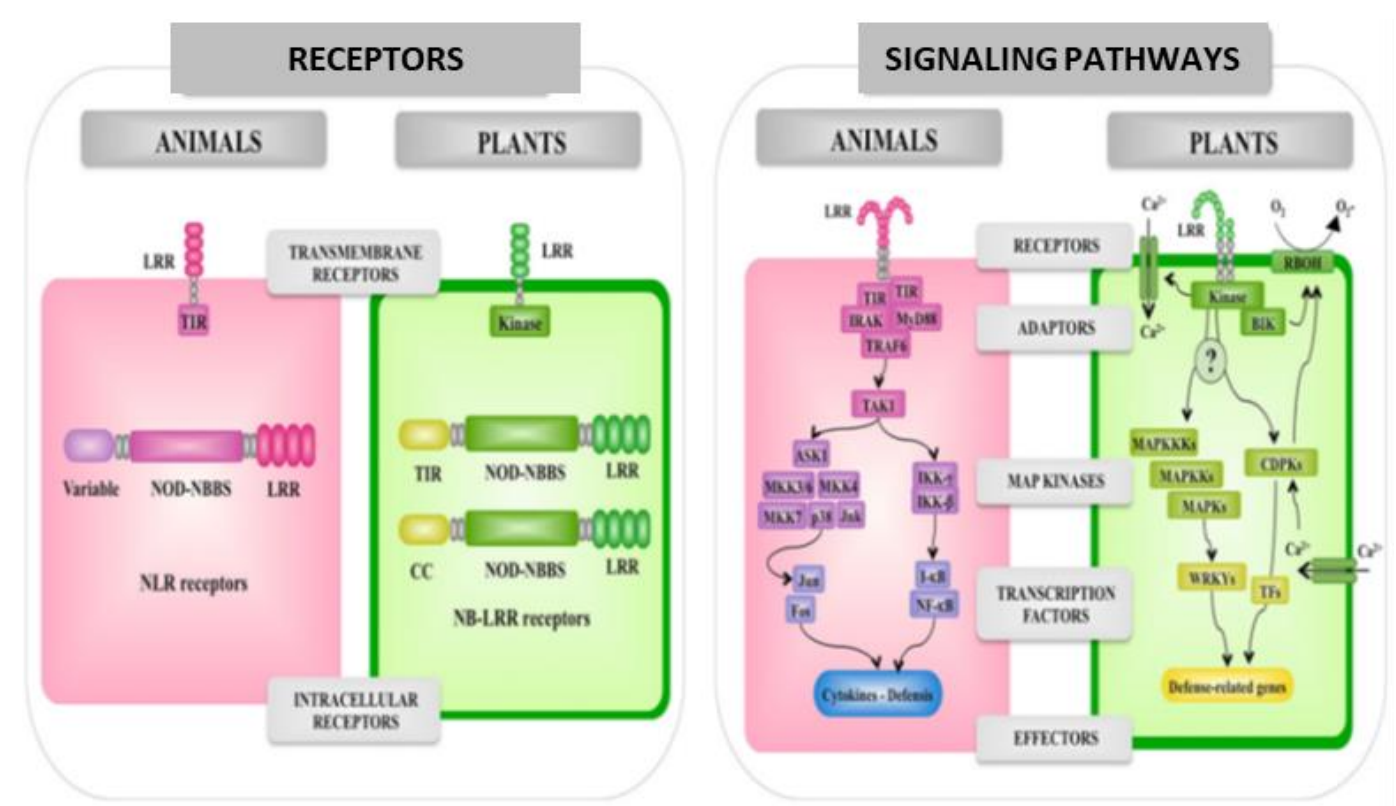

Figure 1 Comparison of the pattern recognition receptors and signaling pathways involved in recognition of pathogenic microorganisms by animal and plant cells. Receptors, adaptors, signaling pathways, and effectors involved in the response of animal and plant cells to microbes are shown. Leucine-rich repeat (LRR), Toll/interleukin-1 receptor (TIR), nucleotide-binding oligomerization domain (NOD), myeloid differentiation primary response 88 (MyD88), TNF receptor-associated factor (TRAF), interleukin-1 receptor-associated kinase (IRAK), mitogen-activated protein kinase (MAPK), mitogen-activated protein kinase kinase (MAPKK), mitogen-activated protein kinase kinase kinase (MAPKKK), WRKY transcription factor (WRKY), nuclear 
factor kappa B (NF-kB), calcium-dependent protein kinase (CDPK), transcription factor (TF). NADPH oxidases are designated as $\mathrm{RBOH}$ in plants [14].

Considering the differences in receptor types and signaling pathways between animals and plants, attempting to determine the right agro-homeopathic remedy based on the comparison of the symptomatology and etiopathogenesis of diseases between the two kingdoms can lead to errors and, eventually, failure. Hence, the comparison of hazards between two phylogenetically distant living systems jeopardizes the validity of the whole homeopathic methodology.

\section{A New Paradigm for Agro-Homeopathy: The Holon Theory}

One of the main difficulties in using highly diluted treatments involves the choice regarding the type of remedy, as well as the scale and level of dilution to be applied. It is imperative to consider that in phytopathology, there is no equivalent of the human homeopathic Materia Medica. Hence, the choice of homeopathic remedy represents the greatest difficulty. The selection of these treatments has thus far been based on an anthropocentric approach [15-17], where the plant is considered similar to a human and the pathological symptoms of the plant are considered, in some ways, similar to those of humans. This method is not completely reliable because of the abovementioned differences between plants and animals. Thus, a three-year Rural Development Program (PSR, grant number 5004957) research project ("Highly diluted preparations for the defense of plants with a low environmental impact on agricultural systems") was conducted and financed by the Department of Agriculture and Food, Hunting, and Fishing of the Emilia-Romagna region. The experimental field research conducted by applying the anthropocentric approach highlighted its limitations and unsustainability. The results showed variable outcomes that were either significant but not repeatable in certain crops, or with contrasting effects in other crops, and/or not significant in yet others (unpublished data).

In this report, the proposed innovative method involves the application of agro-homeopathic treatments, not according to an anthropocentric homeopathic methodology, but according to a systemic agroecological approach. In this approach, the farm is considered to be an agroecosystem, i.e., a complex non-linear system capable of self-regulation. This idea was first developed by Tichavský [18], who coined the term "holo-homeopathy" to indicate homeopathy applied to plants, but with a systemic approach rather than symptomatic views of agronomic problems. It refers to the concept of "holon", coined by Arthur Koestler in 1967 [19], described as a complex system that has individuality, is composed of sub-systems, and is simultaneously a part of a higher-order system. Holon has distinctive characteristics and follows typical behaviors. It is a self-organizing dissipative structure in evolution, composed of smaller holons, called sub-holons, whose structures exist in a balance between chaos and order; it is a self-reliant unit with a degree of independence or autonomy able to withstand disturbances, and has stability. It is dynamic and has a high degree of synergy and collaboration, such that its different components are highly connected. Any change that occurs in one of its parts affects the other parts, and it performs all the functions necessary for its adaptation and survival. The holon is similar to a complex system but has an important difference - if a part of non-vital importance is disconnected in a complex system, it will continue to function with no alterations, whereas, if any part of the holon is modified, its wholeness will be changed. Additionally, unlike complex systems, all parts of the holon contain complete information, thus 
having fractal characteristics. A complex system is not necessarily fractal, while the holon, by definition, has a structure and dynamics based on a high degree of fractality.

In this context, the agricultural farm can be considered an open agroecological system or agroecosystem, which in turn could be incorporated into the holon concept. In particular, the agroecosystem can be identified both as a holon, in the case of a very large farm (more than 1,000 ha) isolated from the surrounding landscape for some geographical reason, or a sub-holon (a part of a holon, expressing all the characteristics at a smaller scale than the holon), as in the case of a small farm (less than 20 ha) located near lakes and forests. The definite answers to particular problems must always be sought within the holon. In some cases, there might be a perfect overlap between the agroecosystem and the holon, while in other cases, the considered agroecosystem could simply be a part of the holon. In such agroecosystems ("holon" or "sub-holons"), a network of interactions between the organisms is involved. Since the colonization of the land by ancestral plant lineages 450 million years ago [20], plants and their associated microbes have been interacting with each other forming a functional entity called the "holobiont", which is an assemblage of species where natural selection occurs between the host and the microbes, and also among the microbes [21]. The farmer, through agricultural practices, intervenes in the agroecosystem and is an integral part of it. All the interactions of an agroecosystem are integrated, creating a network. The systemic homeopathic approach accounts for all the possible interactions between living organisms in an agroecosystem. The terms "holon" and "sub-holons" are used indiscriminately to define agroecosystems. For convenience, the term agroecosystem will be used in the subsequent text.

The systemic agro-homeopathic approach also allows the identification of the "biotype" and "pathogenesis level" of the agroecosystem. The identification of these two characteristics is conducted following the Hahnemannian homeopathic methodology and is aimed at evaluating the nutritional status of the plants or the agroecosystem. A biotype or homeopathic constitution is an association of the morphological, physiological, and psychological characteristics of each subject due to the interaction between the genetic heritage and the environmental conditions in which the subject lives, which makes it unique. For plants, the plant biotype or constitution depends on different factors, such as the genotype and phenotype, environmental and nutritional conditions, relationships with other plants and animals, phenological stage, types of reproduction, and epigenetic factors. Biotypes are not related in a fixed manner with a family of plant, species, or hybrid but display individual patterns of behavioral and morphological plasticity, even when plants are cloned. The best suited homeopathic biotypology model for the specific conditions of plants is the human model of Antoine Nebel (1870-1954), modified by the Brazilian homeopath Roberto Costa [18, 22]. Plants have five individual biotypes or basic constitutions: sulfuric, carbonic, phosphoric, fluoric, and silicic, as shown in Table 2.

Table 2 The five biotypes of plants, the corresponding substances, and their chemical formula $[18,23]$.

\begin{tabular}{lll}
\hline Biotype/Constitution & Substance & Chemical formula \\
\hline Sulfuric & Sulphur & $\mathrm{S}$ \\
Carbonic & Calcarea carbonica & $\mathrm{CaCO}_{3}$ \\
Phosphoric & Calcarea phosphorica & $\mathrm{CaHPO}_{4}$ \\
Fluoric & Calcarea fluorica & $\mathrm{CaF}_{2}$ \\
\hline
\end{tabular}




\begin{tabular}{lll}
\hline Silicic & Calcarea silica & $\mathrm{CaSi}_{2} \mathrm{O}_{5}$ \\
\hline
\end{tabular}

The identification of the biotypes is based on the theory of the predominance of mineral components proposed by Nebel. Based on certain characteristics and the lack or excessive presence of specific mineral components, it is possible to distinguish all biotypes [23]. For example, the Sulfur biotype is biochemically characterized by excellent management of sulfur. From the macroscopic point of view, this biotype is the normotype for excellence. The vegetative development is regular and balanced. The plant is harmonious and symmetrical at the roots and the crown; it responds promptly to climatic and nutritional stresses, etc. Additionally, it is highly adapted to the environment in which it lives. This biotype is therefore balanced in all its proportions and forms and is also quite sturdy. The identification of the biotype allows the determination of only a part of a mineral substance necessary for the plants or the agroecosystem. This information should be integrated with the identification of the pathogenesis level in the agroecosystem to find the specific salt to be applied. In human homeopathy, the pathogenesis level refers to the set of specific pathological symptoms evoked in healthy subjects following the administration of a certain substance. This concept can be transferred to agro-homeopathy; all substances capable of altering the health of the agroecosystem produce a "pathogenic picture" of specific symptoms. An agroecosystem can present six levels of pathogenesis (Table 3 ). These levels, reported by Tichavsky $[18,23]$, were derived from a scheme proposed by Nebel and modified and re-proposed by Bernard $[24]$.

Table 3 The different pathogenesis levels, the corresponding substances, and their cations $[18,23]$.

\begin{tabular}{lll}
\hline Pathogenesis level & Substance & Cation \\
\hline 1-Calcium level & Calcarea carbonica & $\left(\mathrm{CO}_{3} \mathrm{H}\right)->(\mathrm{Ca})^{+}$ \\
2-Magnesium level & Magnesia carbonica & $\left(\mathrm{CO}_{3} \mathrm{H}\right)->(\mathrm{Mg})^{+}$ \\
3-Potassium level & Kalium carbonicum & $\left(\mathrm{CO}_{3} \mathrm{H}\right)->(\mathrm{K})^{+}$ \\
4-Sodium level & Natrum carbonicum & $\left(\mathrm{CO}_{3} \mathrm{H}\right)->(\mathrm{Na})^{+}$ \\
5-Barytic level & Baryta carbonica & $\left(\mathrm{CO}_{3} \mathrm{H}\right)->(\mathrm{Ba})^{+}$ \\
6-Ammonia level & Amonium carbonicum & $\left(\mathrm{CO}_{3} \mathrm{H}\right)->\left(\mathrm{NH}_{4}\right)^{+}$ \\
\hline
\end{tabular}

The different pathogenic pictures present a multiplicity of symptoms, which are related to the excess or deficiency of the chemical element that characterizes the pathogenic level. For each pathogenetic level, there are specific symptoms and bioindicators [23]. For example, the pathogenetic ammonia level is caused by an excess or deficiency of nitrogen. Plants belonging to this level are characterized by excessive vigor and have very soft tissues. Additionally, they react slowly and have difficulties adapting. Moreover, the ammonia level is characterized by the presence of insects with a stinging and sucking buccal apparatus, nitrophilic weeds, and pathologies caused by bacteria and fungi that affect the root and/or foliar apparatus. Plants belonging to different pathogenesis levels can be differentiated by the symptoms in roots, stems, and leaves (excess or lack of mineral elements) and by their resilience to environmental stress. The combination of the biotype with the pathogenesis level, by following the principles of Hahnemannian homeopathic methodology, allows the identification of the "mineral" agro-homeopathic remedy that might 
restore the ideal metabolic and nutritional conditions of the individual plant and the entire agroecosystem. This procedure, i.e., the application of the human biotypes and pathogenesis levels to the plant kingdom, is possible because it involves plant primary metabolism, which is very similar to that of animals. The primary metabolism of plants, or cellular level, is involved in normal growth, development, and reproduction. The primary metabolites include sugars, proteins, fats, amino acids, organic acids, nucleosides, and minerals and usually perform physiological functions in the organism (i.e., an intrinsic function). Table 4 shows the possible combinations between the biotype and pathogenesis level with 30 homeopathic treatments applied in case of imbalance in plant primary metabolism or cellular levels. These remedies are used in centesimal dilution scale (cH), and the dilution/dynamization levels range from 6 to $30 \mathrm{cH}$; however, the most frequently used potencies range from 6 to $12 \mathrm{cH}$.

Table 4 The homeopathic treatments derived from the combinations between the biotype and pathogenesis level [18, 23].

\begin{tabular}{llllll}
\hline Pathogenesis level & Biotype/Constitution and homeopathic substances & \\
\hline 1-Calcium level & Calcarea & Calcarea & Calcarea & Calcarea & Calcarea \\
& sulphurica & carbonica & phosphorica & fluorica & silica \\
2-Magnesium level & Magnesia & Magnesia & Magnesia & Magnesia & Magnesia \\
& sulphurica & carbonica & phosphorica & fluorica & silica \\
3-Potassium level & Kalium & Kalium & Kalium & Kalium & Kalium \\
& sulphuricum & carbonicum & phosphoricum & fluoricum & silicum \\
4-Sodium level & Natrum & Natrum & Natrum & Natrum & Natrum \\
& sulphuricum & carbonicum & phosphoricum & fluoricum & silicum \\
5-Barytic level & Baryta & Baryta & Baryta & Baryta & Baryta \\
& sulphurica & carbonica & phosphorica & fluorica & silica \\
& Amonium & Amonium & Amonium & Amonium & Amonium \\
& sulphuricum & carbonicum & phosphoricum & fluoricum & silicum \\
\hline
\end{tabular}

Another important aspect of agro-homeopathic remedies is that they do not replace the use of the mineral fertilizers of vegetable origin in the agroecosystem. The agro-homeopathic treatment gives a strong but temporary signal to restore system mineral deficiencies and to improve the absorption and mineral metabolism in plants, as well as the soil quality. Subsequently, the farmer implements the correct agronomic techniques.

The selection procedure for the mineral homeopathic remedy does not work for phytopathological diseases (virus, bacteria, or fungi) or pest attacks.

\section{From the Principle of Similarity to Metabolic Similarity}

According to the principles of homeopathy, plant diseases are considered as imbalances (symptoms) to be inserted into a broader pathological framework that encompasses the entire farm. The systemic agro-homeopathic method proposed here is aimed at identifying and treating the cause of the imbalance, thereby attempting to return the system to its homeostatic state. In such an approach, the first phase involves a careful qualitative-quantitative analysis of the agroecosystem, using tools (such as the Voronoi analysis, particle size analysis, refractometry, etc.) 
that aid in the evaluation of the parameters, including biodiversity, soil vitality, mineral substance bioavailability, and the degree of resilience of the entire system [18]. Based on the results of the first preliminary phase (or general analysis of the agroecosystem), the agro-homeopathic preparations to be applied in the field are then selected. In case of abiotic stress, causing nutritional imbalance, the procedure consists of the identification of a mineral agro-homeopathic treatment according to the biotype and pathogenesis level, as discussed above; whereas, for diseases caused by biotic stress (fungi, bacteria, or virus) and for pest control, the application of classical Hahnemann similarity principle does not work, and the differences between plants and animals have to be considered, otherwise, there is a high risk of trivializing the method and for the application to fail. Thus, the principle of similarity has to be accompanied by the concept of "metabolic similarity". This new concept is based on the presence of substances called secondary metabolites in plants and animals and was developed by Tichavsky [18] based on the scientific evidence published in the USDA Duke's database [25]. Plants produce primary metabolites (common to all plants) and secondary metabolites, which are biologically active, species-specific, and organo-specific substances present at very low concentrations. The secondary metabolites from plants are differentiated from primary metabolites, as their role is not crucial for normal growth, development, and reproduction, but they can provide protection to plants from potential harm in the environment; they are also involved in interplant communication (for example in the allelopathic interactions) and can serve as an adaptation tool. Therefore, they are usually synthesized in plants for specific functions, while the primary metabolites generally have shared biological purposes across all species [26, 27]. The selection method proposed by Tichavsky, based on the law of metabolic similarity, can identify, with extreme precision, the homeopathic simillimum or constitutional remedy for each plant species of agricultural interest, as well as for each agroecosystem. The metabolic similarity is independent of the genome of the organisms and the current taxonomic group to which it belongs and can be detected between two plants, between higher plants (trees, shrubs, flowering herbs, ferns and fern relatives) and animals, between plants and insects, between plants and fungi, etc. Furthermore, the secondary metabolites are not the direct products of DNA expression (transcription and translation) but have a strong epigenetic base, and therefore, heavily rely on environmental conditions [28, 29]. This finding explains why the systemic agro-homeopathic intervention for the resolution of a specific problem can change as a function of the considered agroecosystem. The metabolic similarity is based on the presence of secondary metabolites that are common between plants and animals present in the agroecosystem. According to this approach, certain diseases or stress-condition affecting a specific plant can be mitigated through the use of either plants or other organisms that have very similar metabolites to the plant in question. By analyzing the agroecosystem within the perimeters of the farm, it is possible to identify organisms, including wild plants, insects, fungi, and animals. Then, by using either the Duke or Pherobase $[25,30]$ public consultation databases, which facilitate detailed search on plants, chemicals (secondary metabolites), bioactivity, and ethnobotany (using scientific or common names), it would be possible to identify those species with the greatest number of metabolites in common with the plant in question or with the disease to be cured. Thus, two plants that have a large number of secondary metabolites in common can be used as agrohomeopathic remedies for one another. According to the systemic agro-homeopathic approach, the degree of interaction between two or more organisms within the agroecosystem is based on the metabolic similarity, i.e., the similarity of the secondary metabolites between the considered organisms. In a host-pathogen interaction, the pathogen should have a high level of metabolic 
similarity with the host so that infection can take place; in the absence of such a similarity, the pathogen would be unable to recognize and attack its host. For example, in the case of insects, they should necessarily possess a certain number of semiochemicals that allow them to deceive the attacked plants. On the other hand, the attacked plants should produce and release a variety of secondary metabolites called "Volatile Organic Compounds", better known as VOCs, as a means to warn other plants of impending danger. The airborne signals can diffuse and reach undamaged plants nearby, giving them the chance to strengthen their defense. The receivers are not limited to conspecifics. Natural enemies can also detect the warning signals and locate the site of VOC emission [31, 32].

Based on the data from Duke's database, the so-called "metabolic tables" have been built for some plant species, allowing the plant with a higher number of metabolites in common with the plant target to be found more easily [18]. Similar metabolic tables can be created for the shared secondary metabolites, and their specific actions can be reported. Using such tables, it is possible to identify, for acute cases, the plant with the highest degree of similarity (highest number of secondary metabolites in common).

Metabolically related species are used to construct Mother Tinctures (TM) and agrohomeopathic preparations through a specific dilution process and subsequent "dynamization", obtaining potencies ranging from $3 \mathrm{cH}$ to $12 \mathrm{cH}$, with concentrations of the starting substances from $<1 \mathrm{ppt}$ to $1 \mathrm{ppm}$. The resultant preparations are, therefore, completely of natural origin and free of pollutants and/or harmful substances (to both operators and the environment). Moreover, these substances improve the environment by excluding the use of synthetic chemical substances, as well as, through very limited use of raw materials. It is worth mentioning that the systemic agrohomeopathic approach does not ignore "good basic agronomy", by applying the best practices for maintaining soil and plant health (natural fertilization, rotation, using green manure, mowing, planting cover crops, applying combinations of organic inputs, crop rotation, and conservation tillage) [33]. Moreover, the agro-homeopathic methodology allows the use of plant material or supplies, preferably from the same farm or its surroundings. These "autochthonous" materials can be used to prepare the agro-homeopathic remedies, utilizing the internal resources of the ecosystem and, hence, reducing costs and making farmers less dependent on the commercially available plant protection products.

The mechanism of action by which agro-homeopathic treatments act is still unknown, but some hypotheses could be proposed, taking the ecological significance of any imbalances caused by abiotic or biotic stress in the agroecosystem into consideration. The plant diseases or weeds represent the reaction of the agroecosystem to restore the equilibrium, following a "triggering event" that had disturbed its previous state - the systemic agro-homeopathic approach tries to identify the cause of the "trigger" that led the agroecosystem to react in that way (pathogen infection, insect infestation, weed spread). In this context, the systemic agro-homeopathic treatments would act on the whole agroecosystem by stimulating its natural, endogenous defenses to make it more resistant to biotic and abiotic stress. Other authors $[10,17]$ had also suggested that homeopathy induced an increase in the plant's natural resistance to pathogens, possibly related to an epigenetic effect of homeopathic dilutions [34, 35]. The suggestion, based on the re-equilibration of the system induced by homeopathic treatments, was supported by Marotti et al. [36]. The authors tested the hypothesis whether wheat seedlings, grown from seeds either poisoned with a sublethal dose of $\mathrm{As}_{2} \mathrm{O}_{3}$ or unpoisoned, showed different significant gene expression profiles after 
the application of ultrahigh diluted $\mathrm{As}_{2} \mathrm{O}_{3}$ (beyond Avogadro's limit) compared to water (control)When comparing the growth in water of poisoned and unpoisoned seeds, most of the genes (85\%) were upregulated. By growing poisoned seeds in the presence of ultrahigh diluted $\mathrm{As}_{2} \mathrm{O}_{3}$ instead of distilled water, a massive reduction in gene expression levels to values comparable to those of control groups was observed for several functional classes of genes. According to the authors, it seemed that the treatment of poisoned seeds with ultrahigh diluted $\mathrm{As}_{2} \mathrm{O}_{3}$ induced a normalization of gene expression by bringing it closer to the basal levels usually occurring in the control plantlets.

\section{Conclusions}

The systemic agro-homeopathic approach considers the farm as a single organism, an agroecosystem of living and non-living elements, which establishes a dense network of interactions. Its purpose is to strengthen and intensify the relationships among the organisms to create a stronger and healthier agroecosystem, involving all the organisms within the agroecosystem. To fulfill this aim, the described approach allows one to control and manage the agricultural processes through the application of highly diluted and dynamized natural substances. The latter might restore the equilibrium in the agroecosystem by stimulating the natural resistance already present in the agrarian system. The identification of the correct mineral remedy, through the biotypes and pathogenesis levels, could allow one to act on the chronic conditions of the agroecosystem (imbalance in plant primary metabolism or cellular levels), whereas, the identification of plant/animal homeopathic remedy, based on the principle of metabolic similarity, might allow the management of the acute conditions (phytopathological diseases).

Till now, the systemic agro-homeopathic approach has been adopted by some farmers in Europe, particularly in Italy, for about six years and it is increasing interest, especially among organic producers. To date, several observations have been reported by farmers (personal communications), providing positive and encouraging perspectives, but some rigorous scientific experimentation at the farm level is needed to validate such results. If statistical data from field trials were to confirm the observations made so far, the systemic agro-homeopathic approach could represent an agroecological production model with a very low energy impact. Additionally, this approach could be in line with the current European community orientation (European Green Deal), which aims to promote a type of sustainable agriculture. In this context, systemic agro-homeopathy would meet the three pillars of sustainability: (1) economic, due to the very low use of raw materials; (2) environmental, by avoiding the use of chemical substances such as fertilizers, pesticides, etc.; and (3) social, with the production of healthy, safe, and high-quality food.

\section{Author Contributions}

Francesco Di Lorenzo, Giovanni Dinelli, Ilaria Marotti and Grazia Trebbi co-wrote this article; Grazia Trebbi provided literature sources and performed paper editing. All authors have read and agreed to the published version of the manuscript.

\section{Competing Interests}

The authors have declared that no competing interests exist. 


\section{References}

1. Majewsky V, Heuwieser, Shah D, Scherr C, Jager T, Betti L, et al. Use of homeopathic preparations in experimental studies with healthy plants. Homeopathy. 2009; 98: 228-243.

2. Betti L, Trebbi G, Majewsky V, Scherr C, Shah-Rossi D, Jäger T, et al. Use of homeopathic preparations in phytopathological models and in field trials: A critical review. Homeopathy. 2009; 98: 244-266.

3. Jäger T, Scherr C, Shah D, Majewsky V, Betti L, Trebbi G, et al. Use of homeopathic preparations in experimental studies with abiotically stressed plants. Homeopathy. 2011; 100: 275-287.

4. Jäger T, Scherr C, Shah D, Majewsky V, Wolf U, Betti L, et al. The use of plant-based bioassays in homeopathic basic research. Homeopathy. 2015; 104: 277-282.

5. Ücker A, Baumgartner S, Sokol A, Huber R, Doesburg P, Jäger T. Systematic review of plantbased homeopathic basic research: An update. Homeopathy. 2018; 107: 115-129.

6. Pulido EE, Boff P, Duarte TS, Boff MI. Preparados homeopáticos en el crecimiento y en la producción de repollo cultivado en sistema orgánico. Hortic Bras. 2014; 32: 267-272.

7. Pulido $E$, Boff $P$, Duarte $T$, Boff MI. High dilution preparations for organic production system of broccoli. Agron Colomb. 2017; 35: 53-58.

8. Betti L, Trebbi G, Marotti I, Bregola V, Bosi S, Di Silvestro R, et al. Cavolfiore (Brassica oleracea L.) coltivato in regime biologico: Valutazione fitopatologia e nutraceutica. Proceedings of the XXXVIII National Congress of Italian Society for Agronomy; 2009 September 21-23; Firenze, Italy.

9. Toledo MV, Stangarlin JR, Bonato CM. Controle da pinta preta e efeito sobre variáveis de crescimento em tomateiro por preparados homeopáticos. Summa Phytopathol. 2015; 41: 126132.

10. Trebbi G, Nipoti P, Bregola V, Brizzi M, Dinelli G, Betti L. Ultra high diluted arsenic reduces spore germination of Alternaria brassicicola and dark leaf spot in cauliflower. Horticul Bras. 2016; 34: 318-325.

11. Aversa R, Petrescu RV, Apicella A, Petrescu FI. About homeopathy or "Similia Similibus Curentur». Am J Eng Appl Sci. 2016; 9: 1164-1172.

12. De Souza Goncalves PA, Boff P, De Araujo ER. High dilutions dinamized of calcium nitrate and potassium sulphate on the management of thrips, downy mildew and onion yield under organic system. Revista Thema. 2017; 14:16-24.

13. Goncalves AC, Gonçalves dos Santos M, Schwantes D, Stangarlin JR, De Vasconcelos ES, Benetoli da Silva TR, et al. Development of wheat plants treated with nux vomica and grown in soil contaminated with Cd and Pb. J Agronomic Sci. 2017; 6: 70-83.

14. Villena J, Kitazawa H, Van Wees SC, Pieterse CM, Takahashi H. Receptors and signaling pathways for recognition of bacteria in livestock and crops: Prospects for beneficial microbes in healthy growth strategies. Front Immunol. 2018; 9: 2223.

15. Bonfim FP, Martins ER, Dores RG, Barbosa CK, Casali VW, Honório IC. Use of homeopathic Arnica montana for the issuance of roots of Rosmarinus officinalis L. and Lippia alba (Mill) N.E.Br. Int J High Dilution Res. 2008; 7: 113-117.

16. Santos FM, Monfort LE, Castro DM, Pinto JE, Leonardi M, Pistelli L. Characterization of essential oil and effects on growth of Verbena gratissima plants treated with homeopathic Phosphorus. Nat Prod Commun. 2011; 6: 1499-1504. 
17. Modolon TA, Boff $\mathrm{P}$, Boff $\mathrm{MI}$, Miquelluti DJ. Homeopathic and high dilution preparations for pest management to tomato crop under organic production system. Horticul Bras. 2012; 30: 51-57.

18. Tichavský R. Organon de la Holohomeopatia. Saltillo, Coahuila, Mexico: Quintanilla Ed; 2008.

19. Koestler A. The ghost in the machine. London: Hutchinson; 1967.

20. Sanderson MJ, Thorne JL, Wikström N, Bremer K. Molecular evidence on plant divergence times. Am J Bot. 2004; 91:1656-1665.

21. Hassani MA, Durán $\mathrm{P}$, Hacquard S. Microbial interactions within the plant holobiont. Microbiome. 2018; 6: 1-17.

22. Costa RA. Homeopatia atualizada. 2nd ed. Petrópolis: Vozes; 1984.

23. Tichavský R. Biotipologia agrohomeopatica. In: Homeopatia para las plantas. Monterrey Mexico. Ed. Fujimoto Promociones S.A. de C.V., Mexico. 2009: 108-124

24. Bernard H. Traité de médecine homéopathique. Angouleme: Ed Coquemard; 1951.

25. Dr. Duke's Phytochemical and Ethnobotanical databases. Available from: https://phytochem.nal.usda.gov/phytochem/search.

26. Kabera JN, Semana E, Mussa AR, He X. Plant secondary metabolites: Biosynthesis, classification, function and pharmacological properties. J Pharm Pharmacol. 2014; 2: 377-392.

27. Hussein RA, El-Anssary AA. Plants secondary metabolites: The key drivers of the pharmacological actions of medicinal plants. In: Herbal medicine. London, UK: IntechOpen; 2019.

28. Gacek A, Strauss J. The chromatin code of fungal secondary metabolite gene clusters. Appl Microbiol Biotechnol. 2012; 95: 1389-1404.

29. Pfannenstiel BT, Greco C, Sukowaty AT, Keller NP. The epigenetic reader SntB regulates secondary metabolism, development and global histone modifications in Aspergillus flavus. Fungal Genet Biol. 2018; 120: 9-18.

30. The Pherobase: Database. Available from: https://www.pherobase.com.

31. Bouwmeester $H$, Schuurink RC, Bleeker PM, Schiestl F. The role of volatiles in plant communication. Plant J. 2019; 100: 892-907.

32. Ueda H, Kikuta Y, Matsuda K. Plant communication mediated by individual or blended VOCs? Plant Signal Behav. 2012; 7: 222-226.

33. Tully KL, McAskill C. Promoting soil health in organically managed systems: A review. Org Agric. 2020; 10: 339-358.

34. Das D, De A, Dutta S, Biswas R, Boujedaini N, Khuda-Bukhsh AR. Potentized homeopathic drug Arsenicum Album $30 \mathrm{C}$ positively modulates protein biomarkers and gene expressions in Saccharomyces cerevisae exposed to arsenate. J Chin Integr Med. 2011; 9: 752-760.

35. De A, Das D, Dutta S, Chakraborty D, Boujedaini N, Khuda-Bukhsh AR. Potentiated homeopathic drug Arsenicum album 30C inhibits intracellular reactive oxygen species generation and upregulates expression of arsenic resistance gene in arsenite-exposed bacteria Escherichia coli. J Chin Integr Med. 2012; 10: 210-227.

36. Marotti I, Betti L, Bregola V, Bosi S, Trebbi G, Borghini G, et al. Transcriptome profiling of wheat seedlings following treatment with ultrahigh diluted arsenic trioxide. Evid-based Complement Alternat Med. 2014; 2014. DOI: 10.1155/2014/851263. 


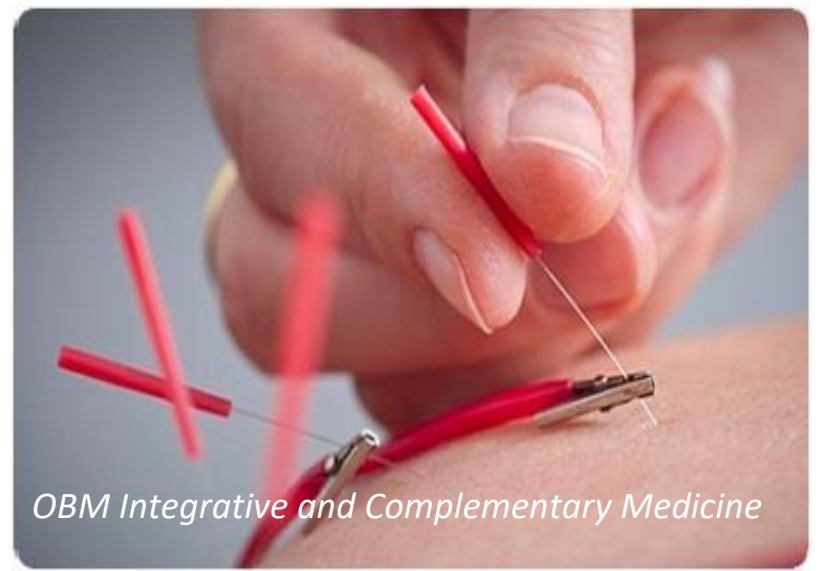

Enjoy OBM Integrative and Complementary Medicine by:

1. Submitting a manuscript

2. Joining in volunteer reviewer bank

3. Joining Editorial Board

4. Guest editing a special issue

For more details, please visit:

http://www.lidsen.com/journals/icm 